DEPARTMENT OF THE INTERIOR

U. S. GEOLOGICAL SURVEY

\title{
HYDROLOGIC UNIT MAP-1974
}

STATE OF OREGON

Prepared in cooperation with the

U. S. WATER RESOURCES COUNCIL

Published by the U. S. Geological Survey, 1976

Reston, Virginia 22092

Reprinted 1989 